\title{
The Financial Factors Affecting the Financial Performance of Philippine MSMEs
}

\author{
John Guay Pagaddut \\ College of Business and Management, Ifugao State University, Lagawe, 3600, Ifugao, Philippines
}

Received September 13, 2021; Revised October 13, 2021; Accepted November 21, 2021

\section{Cite This Paper in the following Citation Styles}

(a): [1] John Guay Pagaddut , "The Financial Factors Affecting the Financial Performance of Philippine MSMEs," Universal Journal of Accounting and Finance, Vol. 9, No. 6, pp. 1524-1532, 2021. DOI: 10.13189/ujaf.2021.090629.

(b): John Guay Pagaddut (2021). The Financial Factors Affecting the Financial Performance of Philippine MSMEs. Universal Journal of Accounting and Finance, 9(6), 1524-1532. DOI: 10.13189/ujaf.2021.090629.

Copyright $\bigcirc 2021$ by authors, all rights reserved. Authors agree that this article remains permanently open access under the terms of the Creative Commons Attribution License 4.0 International License

\begin{abstract}
Micro, small and medium enterprises (MSMEs) are considerably contributory to social and economic progress and prosperity through their entrepreneurial capacities and capabilities. However, they experience constraining challenges that importunately impair their abilities, failing to optimally engage themselves in the privileging opportunities around, particularly in the financial aspect. This paper aims to establish the financial factors affecting the financial performance of Philippine MSMEs whose audited financial statements are utilized to extract financial ratios needed for the study. It also aims to determine the factor structure that can explain the variation among these financial factors and to determine the cohesive cluster that can separate these financial factors. It employed multiple linear regression, factor analysis and cluster analysis in order to respectively achieve its objectives. It establishes that debt ratio, asset turnover and gross profit margin have a significant effect on return on assets. It further establishes that there are two significant factor structures, namely "Sustainability" ratios and "Efficiency" ratios, explaining the variation among these financial ratios. It furthermore establishes that there are two cohesive clusters, namely "good" ratios and "poor" ratios, separating these financial ratios. It suggests that MSMEs should remain self-sufficient and self-reliant, without unreasonably depending on debts, hence should adequately afford capital to finance their businesses. Further, they should optimally operate to generate sales by efficiently employing their resources. Furthermore, they should judiciously control costs, without compromising quality of their products and services, in order to increase their margin. They should
\end{abstract}

reinforce their performance by regularly advancing their efficiency and sustainability. They should work well to sustain good ratios and improve poor ratios. Notably, this paper suggests that stakeholders sustainably support MSMEs in light of creativity and collaboration.

Keywords MSMEs, Financial Factors, Financial Performance, Philippines

\section{Introduction}

Micro, small and medium enterprises (MSMEs) are considerably contributory to social and economic progress and prosperity through their entrepreneurial capacities and capabilities. Globally, they drive economic growth and equitable development [1]. Geographically distributed producing for the world economies [2], they significantly share $90 \%$ of the global entities that substantially supply $70 \%$ of the global employment [3]. Remarkably then, they are exceptionally and extensively supported by governments because they will responsibly render the 600 million jobs predicted in 2030 [4]. Indispensably influential to driving universal sustainability, MSMEs distinctly define the efficiency and effectiveness of world economies.

Regionally, MSMEs are vital vehicles of employing peoples, generating incomes and producing outputs. Particularly in Europe, MSMEs account for $99 \%$ of the total enterprises, and employ $66 \%$ of the total occupations and manufacture $56 \%$ of total value-added products of the 
European economy [5]. Particularly further in Southeast Asia, they occupy $88.8 \%$ to $99.9 \%$ of the total businesses, affording $51.7 \%$ to $97.2 \%$ of the total employments and creating $30 \%$ to $53 \%$ of the total Gross Domestic Product in the region [6]. Being resilient against and responsive to changes [7], MSMEs then stand the strong spine of these regional economies as they sustainably spring values thereto.

Locally, MSMEs meaningfully machine the Philippine economy. Continually growing, they advance the nation by adding vital value thereto [8]. Specifically, the Philippine Statistics Authority [9] highlighted that MSMEs impact $35.7 \%$ to the national valued-added - micro, $4.9 \%$, small $20.5 \%$ and medium, $10.3 \%$. Specifically, the 2019 MSME Statistics underscored that while MSMEs number to 995,745 , accounting for $99.5 \%$ of the total establishments, they only employ $5,510,760$, accounting for only $62.40 \%$ of the total employment.

Most significantly, MSMEs drive innovation which in turn drives country-wide prosperity, hence be "fostered, safeguarded and incentivised" [10]. Societal, commercial and governmental entities then embark on collaboration to optimize innovation in light of applicable laws and frameworks [11]. As such, MSMEs share the significant spotlight in the Philippine laws that solidly state their utmost prioritization and promotion by the government in view of their immense importance.

Notably, the Magna Carta for Small Enterprises, the Barangay Micro Business Enterprises (BMBEs) Act of 2002 and the Go Negosyo Act purvey essential provisions to reasonably prosper MSMEs in fuelling the national economy, hence necessitating the reinforcing empowerment and engagement of MSMEs. Pursuant thereto, MSMEs are afforded with governmental and intergovernmental provisions. The MSME Development Program 2017-2022 summons the profound collaboration of state agencies aimed to empower the commercial atmosphere where MSMEs can boldly build their potentials [12]. Additionally, the ASEAN Strategic Action Plan for SME Development 2016-2025 calls for proactive stakeholder cooperation being decisively directed to engage integration and internationalization through which MSMEs can optimize the opportunity of global growth [13]. These programs then primarily visualize "globally competitive and innovative MSMEs" towards relevant and responsive efficiency, effectiveness and sustainability.

These remarkable efforts are purposefully positioned to prosper MSMEs. However, they successively struggle through differing drawbacks that incessantly impede their progression. Being problems themselves [14], globalization and liberalization increased the challenges and competitions that burden MSMEs, despite the improving promotional measures and business opportunities around [15]. They intractably intensify their participation in the international market due to limited comprehension and competencies and due to limited money and market access [16]. In corresponding contexts, MSMEs undergo resource challenges in terms of men, money, measures, markets and materials [17, 18]. Particularly, they hardly thrive due to insufficiency of income and infrastructure, inaccesibility to care and credit, inadequacy of comprehension and competencies, due to inefficiencies and ineffectiveness [19]. Consequently, they are vulnerably disadvantaged in key areas of capital and commerce and of labour and logistics [20]. Had these factors been well collaborated and coordinated, they could have enhanced economic growth and business competitiveness [21].

Primarily topping these challenges that ceaselessly crush MSME abilities are financial concerns [22] among which is how they financially perform being an interest of different stakeholders. Technically, financial performance conveys how an entity employs its resources to achieve its entrepreneurial goals. It is analytically assessed through financial reports being instrumental in conveying how MSMEs accountably and economically position themselves [23]. Specifically, ratio analysis is the quantitative examination of information conveyed by the financial reports [24]. It can be numerously measured, principally in terms of profits or returns, e.g. return on assets [25], contingent on the research contexts [26]. Captivatingly, MSMEs are capacitated to overcome whatever challenges that burden them when they financially perform well [27]. This study then draws attention to what financial factors in terms of financial ratios can boost the financial performance of MSMEs.

Financial ratios are instrumental in evaluating financial performance [28]. Articulating the direct relationship between two figures derived from financial statements, they provide information regarding how proficiently performing establishments are and how optimally operating they are [29]. Insightfully communicating vital facts that can help stakeholders best make decisions, they include liquidity, leverage, efficiency and profitability ratios [30].

Accordingly, liquidity ratios measure the ability to discharge liabilities using the assets while leverage ratios measure the ability to use capital through the optimal mixture of liabilities and equity. Meanwhile, efficiency ratios measure the ability to wisely expend resources while profitability ratios measure the ability to optimally earn a peso from each peso asset utilized. Financial ratios then are valuable evaluative instruments of financial performance [31].

A certain framework of the importance and influence of financial ratios on financial performance is suggested to be contextualized in different researches that deal thereabout [28]. Such framework identified ratios, namely liquidity, leverage, efficiency and profitability, as the independent variables onto which financial performance, being the dependent variable, will be regressed. Hence, this paper uses current ratio, debt ratio, asset turnover ratio, gross 
profit margin ratio and return on assets being reasonably calculated from MSME financial reports.

The analytical study of financial performance through financial ratios affords information on how to better make decisions and actions towards better efficiency and effectiveness. It also identifies opportunities and obstacles, informing the entities on how to maximize the former and how to minimize the latter. As such, the analysis of financial performance affords MSMEs to soundly perform entrepreneurial sustainability. Accordingly, knowledge on how MSMEs perform springs forth the knowledge on how MSMEs sustain against setbacks [28].

Diligently searching through the past five-year literature, this study found no other research published in respectably refereed journals issued by non-predatory publishers, that specifically worked on financial factors, particularly financial ratios, affecting the financial performance, as measured by Return on Assets, of Philippine MSMEs. However, it considered to examine studies on financial factors affecting the financial performance of MSMEs, in their respective contexts and variables.

Cammayo and Cammayo [32] studied financial performance measured by return on assets among other ratios. However, it was regressed on financial practices among 227 MSMEs in Isabela, Philippines. They determined that Isabela MSMEs poorly perform at a very low return on assets. Intriguingly, they also revealed that financial practices, which is mainly indicated by bookkeeping and budgeting among others have a significant association with financial performance mainly indicated by return on assets among others. They suggested that these entities should be proficient in accounting and financing.

Suparlinah et al. [33] also studied financial performance being regressed on funding, financial literacy, among others. Using regression, they provided that funding significantly and negatively affect the performance of 75 MSMEs in Banyumas Regency, Indonesia, while financial literacy significantly and positively affect such performance. They suggested that these entities should focus on funding and on financial literacy, to include business size in order to improve their performance.

Ombongi and Long [27] also studied financial performance measured by profits regressed on credit from banks, employee costs, technological costs, and gross domestic products among 682 MSMEs in Kenya. Using regression, they determined that these regressors exude significant direct relationship with the MSME financial performance. They suggested that stakeholders ascertain primarily financing to be adequately accessible for MSMEs.

Ratnawati [34] established that financial inclusion has a significant direct and indirect effect on financial performance of 100 MSMEs in Malang City, Indonesia. Utilizing Partial Least Squares model, she further established that the quality of financial services and access to financial financing improve the workforce growth, profit growth, market share growth and sales growth of these entities. Interestingly, such effect is better mediated by financial intermediation than the access to capital. Particularly, market penetration and service quality better boost the effect of financial inclusion on financial performance.

Ni'matulHoiroh et al. [35] substantiated through multiple linear regression that financial literacy and human resources, including the use of accounting information system, have significant effect on the performance of 100 MSMEs in Malang City, Indonesia. Thus, financing people, among other business employees, can significantly affect how MSMEs perform. How equipped they are with financial comprehension and competencies can spell out the resulting peforming abilities of these businesses.

In light of the gap, predominantly the absence of specific study on the financial factors affecting the financial performance, establishing the effect of financial ratios on financial performance of Philippine MSMEs, the structure explaining the variance among these financial ratios into factors and the cluster separating these financial ratios. The study proceeds to conduct its research in order to generate information affording MSME management to create their managerial and operational decisisons and actions based on how financial ratios affect their financial performance. Further, it allows investors and creditors to soundly craft their investing and lending activities towards MSMEs. Furthermore, it provides information for governmental, organizational and social entities whom they can ask support to further their abilities.

This study asks the following questions.

1) Is there a significant effect of the financial factors on the financial performance of Philippine MSMEs?

2) Is there a factor structure that can adequately explain the variation among the financial factors affecting the financial performance of Philippine MSMEs?

3) Is there a cohesive clustering that can separate the financial factors affecting the financial performance of Philippine MSMEs?

\section{Materials and Methods}

\subsection{Research Methods}

This study used multiple linear regression, factor analysis and cluster analysis in order to respectively achieve its objectives. Further, it employed explanatory research design as it aims to explain the effect of the independent variables on the dependent variable. Furthermore, it employed exploratory research design as it aims to explore on the structure and cluster that can 
emerge from the factor analysis and cluster analysis, respectively.

\subsection{Population, Sample and Sampling Procedure}

This study researched on the financial factors affecting the financial performance of Philippine MSMEs that are nationally figuring to $995,745.00$ and regionally numbering 202,011.00 in the National Capital Region for year 2019. It sampled 40 MSMEs resulting from applying convenience sampling. It used 80 audited financial statements for years 2018 and 2019 that were respectfully requested from a certain Manila-based audit firm, granting permission on the use thereof.

\subsection{Data Gathering Instruments}

This study extracted particularly the financial ratios from the audited financial statements of 40 MSMEs for years 2018 and 2019 using applicable formula. Current ratio is computed by dividing current assets by the current liabilities while debt ratio is computed by dividing the total liabilities by the total assets. Asset turnover is derived by dividing total revenues by the average total assets while gross profit margin is derived by dividing the gross profit by the total revenues. Being the measure of the firm's ability to generate profit from exhausting its assets, return on assets is obtained by dividing the net income by the average total assets. Hagel et al., as cited by El-Ansary and Al-Gazzar [36], underlines that Return on Assets best measures financial performance as it is the best financial indicator of the health of the firm.

\subsection{Treatment of Data}

This study utilized mean and standard deviation relative to descriptive analysis of the study and further operated (1) Linear Regression, (2) Barlett's Test of Sphericity, Kaiser - Meyer - Olkin Test of Sampling Adequacy, Eigenvalues and (3) Silhouette Coefficient and Separation from Two-step Cluster relative to the inferential analyses of the study.

This study then writes the following regression statement.

$$
\mathrm{ROA}=\beta 0+\beta 1 \mathrm{CR}+\beta 2 \mathrm{DR}+\beta 3 \mathrm{AT}+\beta 4 \mathrm{GPR}+\varepsilon
$$

Where,

$$
\begin{aligned}
\mathrm{ROA} & =\text { return on assets (dependent variable) } \\
\beta 0 & =\text { intercept } \\
\beta 1 & =\text { regression coefficient }(\mathrm{CR}) \\
\beta 2 & =\text { regression coefficient }(\mathrm{DR}) \\
\beta 3 & =\text { regression coefficient }(\mathrm{AT}) \\
\beta 4 & =\text { regression coefficient }(\mathrm{GPR}) \\
\mathrm{CR} & =\text { current ratio } \\
\mathrm{DR} & =\text { debt ratio } \\
\mathrm{AT} & =\text { asset turnover ratio } \\
\mathrm{GPR} & =\text { gross profit margin ratio }
\end{aligned}
$$

$$
\varepsilon=\text { error term }
$$

\section{Results and Discussions}

\subsection{Descriptive Statistics}

It is shown in Table 1 that there are 80 observations for each of the variables. Accordingly, Return on Assets (ROA) has a mean of -.975 and a standard deviation of 7.3556. Accordingly, Current Ratio (CR) has a mean of 8.887 and a standard deviation of 20.9482 while Debt Ratio has a mean of 1.796 and standard deviation of 4.2951. Furthermore, Asset Turnover (AT) has a mean of 3.507 and a standard deviation of 5.9412 while Gross Profit Margin (GPR) has a mean of .190 and a standard deviation of .3987 .

\subsection{Correlation between Variables}

The correlation between variables is shown in Table 2. Specifically, Current Ratio (CR) and Gross Profit Ratio (GPR) are positively correlated with Return on Assets (ROA), at .058 and at .252 respectively. Further, Debt Ratio (DR) and Asset Turnover (AT) negatively correlated with Return on Assets (ROA), at -.699 and at -.769 respectively. Debt Ratio, Asset Turnover Ratio and Gross Profit Ratio exude significant relationship with Return on Assets, at $\mathrm{p}$ value of $.000, .000$ and .012 correspondingly while Current Ratio exhibits no significant relationship with Return on Assets at $p$ value of .304 .

Table 1. Descriptive Statistics

\begin{tabular}{|c|c|c|c|}
\hline & Mean & Std. Deviation & N \\
\hline ROA & -.975 & 7.3556 & 80 \\
\hline CR & 8.887 & 20.9482 & 80 \\
\hline DR & 1.796 & 4.2951 & 80 \\
\hline AT & 3.507 & 5.9412 & 80 \\
\hline GPR & .190 & .3987 & 80 \\
\hline
\end{tabular}

Table 2. Correlation between Variables

\begin{tabular}{|c|c|c|c|c|c|c|}
\hline & & ROA & CR & DR & AT & GPR \\
\hline \multirow{4}{*}{$\begin{array}{c}\text { Pearson } \\
\text { Correlation }\end{array}$} & ROA & 1.000 & .058 & -.699 & -.769 & .252 \\
\cline { 2 - 7 } & CR & .058 & 1.000 & -.074 & -.142 & .068 \\
\cline { 2 - 7 } & DR & -.699 & -.074 & 1.000 & .566 & .019 \\
\cline { 2 - 7 } & AT & -.769 & -.142 & .566 & 1.000 & -.154 \\
\cline { 2 - 7 } & GPR & .252 & .068 & .019 & -.154 & 1.000 \\
\hline \multirow{4}{*}{$\begin{array}{c}\text { Sig. } \\
(1-\text { tailed) }\end{array}$} & ROA &. & .304 & .000 & .000 & .012 \\
\cline { 2 - 7 } & CR & .304 &. & .258 & .104 & .274 \\
\cline { 2 - 7 } & DR & .000 & .258 &. & .000 & .432 \\
\cline { 2 - 7 } & AT & .000 & .104 & .000 &. & .086 \\
\cline { 2 - 7 } & GPR & .012 & .274 & .432 & .086 &. \\
\hline
\end{tabular}




\subsection{Multiple Linear Regression}

It is shown in Table 3 that the variables exude no auto-correlation since the Durbin-Watson is 1.756 and exude no multi-collinearity since the Variance Inflation Factor (VIF) values are below 5. Normally distributed as shown by the bell-shaped distribution, they do not include outliers. The model therefore satisfies the regression assumptions.

This study also shows that the model fit is substantially predictive at $72.9 \%, \mathrm{R} 2$, better yet at $71.4 \%$, adjusted R2. Sarstedt, Ringle and Hair [37] established that an R2 of $0.25,0.50$, and 0.75 represents weak, moderate and substantial predictive accuracy of the model. Particularly, the set of independent variables, namely Current Ratio, Debt Ratio, Asset Turnover and Gross Profit Margin, can substantially predict $71.4 \%$ of the variation in the dependent variable namely Return on Assets. Importantly, the model is significant at $\mathrm{p}$ value of 0.00 .

This study also shows that there exists a significant effect of three independent variables, among the four, on the dependent variable. Debt ratio has significant negative effect on return on assets $(p=0.000, \beta=-.714)$. Asset turnover has a significant negative effect on return on assets $(p=0.000, \beta=-.635)$. Gross Profit Margin has a significant positive effect on return on assets $(\mathrm{p}=0.004, \beta=$ 3.414). Current Ratio however has no significant effect on return on assets, $(p=0.342, \beta=-.020)$.
From these results, this study then articulates the following regression equation.

$$
\begin{gathered}
\mathrm{ROA}=2.066+-.020 \mathrm{CR}+-.714 \mathrm{DR}+-.635 \mathrm{AT}+ \\
3.414 \mathrm{GPR}+\varepsilon
\end{gathered}
$$

Notably, ROA computes 2.066 when the regressors score zero. However, ROA decreases by .714 for every percent increase in DR, assuming all other factors constant. However further, it decreases by .635 for every percent increase in AT, assuming all other factors constant. Interestingly, it increases by 3.414 for every percent increase in GPR, assuming all other factors are constant.

Debt Ratio having a significant negative effect on Return on Assets means that employing substantial debt in funding entity resources reduces the financial performance of Philippine MSMEs. The higher amount of debt they use, the less they perform. Being limited in finances, MSMEs resort to borrowing, which is costly primarily in terms of interests and penalties that significantly dominate expenses. While they are afforded with loans by formal institutions, they rather recourse to borrowing from those informal sectors like 5' 6 ' being easily accessed to without securing much requirements. However, it turns out that these informal loans burden them with higher interest rates which can eventually eat them up. Interestingly, Rita and Utomo [38] cited Bohner and Dickel who discoursed that a strategy to grow businesses is to secure investments as a main stream of funding.

Table 3. Regression Results

\begin{tabular}{|c|c|c|c|c|c|}
\hline \multicolumn{5}{|c|}{ Model Summary $^{\mathbf{b}}$} \\
\hline Model & $\mathrm{R}$ & R Square & Adjusted R Square & $\begin{array}{c}\text { Std. Error of the } \\
\text { Estimate }\end{array}$ & Durbin - Watson \\
\hline 1 & $.854^{\mathrm{a}}$ & .729 & .714 & 3.9310 & 1.756 \\
\hline
\end{tabular}

\begin{tabular}{|c|c|c|c|c|c|c|c|c|c|}
\hline \multicolumn{10}{|c|}{ Coefficients $^{a}$} \\
\hline \multirow[t]{2}{*}{ Model } & \multicolumn{2}{|c|}{$\begin{array}{l}\text { Unstandardized } \\
\text { Coefficients }\end{array}$} & \multirow{2}{*}{$\begin{array}{c}\begin{array}{c}\text { Standardized } \\
\text { Coefficients }\end{array} \\
\text { Beta }\end{array}$} & \multirow[t]{2}{*}{$\mathrm{t}$} & \multirow[t]{2}{*}{ Sig. } & \multicolumn{2}{|c|}{$\begin{array}{l}95.0 \% \text { Confidence Interval } \\
\text { for B }\end{array}$} & \multicolumn{2}{|c|}{$\begin{array}{l}\text { Collinearity } \\
\text { Statistics }\end{array}$} \\
\hline & B & Std. Error & & & & $\begin{array}{l}\text { Lower } \\
\text { Bound }\end{array}$ & $\begin{array}{l}\text { Upper } \\
\text { Bound }\end{array}$ & Tolerance & VIF \\
\hline (Constant) & 2.066 & .610 & & 3.386 & .001 & .851 & 3.282 & & \\
\hline $\mathrm{CR}$ & -.020 & .021 & -.058 & -.956 & .342 & -.063 & .022 & .978 & 1.023 \\
\hline DR & -.714 & .126 & -.417 & -5.672 & .000 & -.965 & -.463 & .668 & 1.496 \\
\hline AT & -.635 & .093 & -.512 & -6.844 & .000 & -.819 & -.450 & .645 & 1.551 \\
\hline GPR & 3.414 & 1.134 & .185 & 3.012 & .004 & 1.156 & 5.673 & .957 & 1.045 \\
\hline
\end{tabular}

\begin{tabular}{|c|c|c|c|c|c|}
\hline \multicolumn{7}{|c|}{ ANOVA $^{\mathbf{a}}$} \\
\hline Model & Sum of Squares & df & Mean Square & F & Sig. \\
\hline Regression & 3115.299 & 4 & 778.825 & 50.400 & $.000^{\text {b }}$ \\
\hline Residual & 1158.976 & 75 & 15.453 & & \\
\hline Total & 4274.275 & 79 & & & \\
\hline a. Dependent Variable: ROA \\
\hline b. Predictors: (Constant), GPR, DR, CR, AT
\end{tabular}


Asset Turnover having a significant negative effect on Return on Assets means that generating net sales using larger amount of average assets decreases the financial performance of Philippine MSMEs. The less efficient MSMEs in employing their resources to yield sales, the less they perform. They hardly optimize their ability to generate sales because they are not well equipped with the resources and opportunities amidst the problems that are persistently pressing them down. Illustratively, they fall short in acquiring the technology needed to advance their processes and procedures because they financially suffer. They cannot outdo competitions and cannot overcome phenomena in the market because they are limited.

Gross Profit Margin having a significant positive effect on Return on Assets means that deriving more gross profit from net sales escalates the financial performance of Philippine MSMEs. The more gross profit they obtain, the better they perform. Hence, they should fittingly control the costs of their goods sold so that they can derive more gross profit. Captivatingly, while there are costs that cannot be removed or cannot be reduced, there are those costs that can be discretionarily managed to be removed or to be reduced, without sacrificing the quality of their products and services. On the other hand, Current Ratio having an insignificant negative effect on Return on Assets means that the ability of Philippine MSMEs to discharge their liabilities does not affect their financial performance.

\subsection{Factor Analysis}

The factor analysis results is shown in Table 4, which show firstly that the sampling is adequate for analysis according to the Kaiser-Meyer-Olkin Measure of
Sampling Adequacy valuing at .622, being more than .50 . Secondly, the Bartlett's Test of Sphericity displays statistical significance at .000 , supporting the factorability of the correlation matrix and affording the rejection of the null hypothesis that the original correlation matrix is an identity matrix.

Emerging from the factor analysis are two components exuding total variance of 69.177 . The first Eigen value is equal to 2.417 and explains $48.342 \%$ of the variance in the original data while the second Eigen value is equal to 1.042 and explains $20.835 \%$ of the variance, totalling $69.177 \%$. Entailing factor loadings of .866 and .862 respectively, Debt Ratio and Asset Turnover belong to Factor 1. Entailing factor loadings of .615 and .813 respectively, Current Ratio and Gross Profit Margin belong to Factor 2.

Basing on its theme, this study names Factor 1 as Sustainability Ratios being anchored on the ability of the firm to sustainably thrive through the years. These ratios show how MSMEs can better stabilize through time when provided with adequate assets that are effectively utilized to generate optimal wealth. Having measured how entities utilize resources in the long term, a sound Debt Ratio and Asset Turnover indicates reliable adequacy and resilient continuity.

Basing on its theme, it names Factor 2 as Efficiency Ratios being anchored on the ability of the firm to effectively operate in the current year. These ratios show how MSMEs can better operate regularly when provided with efficient employment of resources. Measuring how entities utilize resources in the short term, a sound current ratio and gross profit margin ratio indicates good liquidity and profitability.

Table 4. Factor Analysis Results

\begin{tabular}{|c|c|c|}
\hline \multicolumn{3}{|c|}{ KMO and Bartlett's Test } \\
\hline \multirow{4}{*}{ Bartlett's Test of Sphericity } & mpling Adequacy. & .622 \\
\hline & Approx. Chi-Square & 134.229 \\
\hline & df & 10 \\
\hline & Sig. & .000 \\
\hline
\end{tabular}

\begin{tabular}{|c|c|c|c|c|c|c|c|c|c|}
\hline \multicolumn{9}{|c|}{ Total Variance Explained } \\
\hline \multirow{2}{*}{ Component } & \multicolumn{7}{|c|}{ Initial Eigenvalues } & Extraction Sums of Squared Loadings & \multicolumn{3}{c|}{ Rotation Sums of Squared Loadings } \\
\cline { 2 - 10 } & Total & $\begin{array}{c}\text { Cumulative } \\
\%\end{array}$ & Total & $\begin{array}{c}\text { Cumulative } \\
\%\end{array}$ & Total & $\begin{array}{c}\% \text { of } \\
\text { Variance }\end{array}$ & $\begin{array}{c}\text { Cumulative } \\
\%\end{array}$ \\
\hline & 2.417 & 48.342 & 48.342 & 2.417 & 48.342 & 48.342 & 2.417 & 48.342 & 48.342 \\
\hline 2 & 1.042 & 20.835 & 69.177 & 1.042 & 20.835 & 69.177 & 1.042 & 20.835 & 69.177 \\
\hline 3 & .958 & 19.155 & 88.333 & & & & & & \\
\hline 4 & .407 & 8.145 & 96.478 & & & & & & \\
\hline 5
\end{tabular}


Table 4 Continued

\begin{tabular}{|c|c|c|}
\hline \multicolumn{3}{|c|}{ Rotated Component Matrix $^{\mathbf{a}}$} \\
\hline & \multicolumn{2}{|c|}{ Component } \\
\hline ROA & 1 & .173 \\
\hline CR & -.919 & .615 \\
\hline DR & -.043 & .111 \\
\hline AT & .866 & -.179 \\
\hline GPR & .862 & .813 \\
\hline a. Rotation converged in 3 iterations. & -.076 & \\
\hline
\end{tabular}

\subsection{Cluster Analysis}

It is shown in Table 5 that since the Silhoutte Measure of Cohesion and Separation is greater than 0.50, then there is a cohesive clustering that can separate the financial factors affecting the financial performance of Philippine MSMEs. According to the cluster distribution, there are two appropriate configurations into which MSME ratios exuding similar characteristics are clustered. Cluster 1 is labelled as "good" ratios while Cluster 2 is labelled as "poor" ratios.

Good ratios indicate efficiency and effectiveness attributed to functional strategies and systems, effectual processes and procedures, operational returns and resources. Contrarily, poor ratios indicate inefficiencies and ineffectiveness caused by entrepreneurial inabilities and incapacities and by internal and external challenges. Hence, MSMEs thoroughly undertake sound planning, implementing, monitoring, evaluating and controlling activities in order to optimize resources and opportunities, while outperforming risks and outdoing weaknesses.

Table 5. Cluster Analysis Results

Model Summary

\begin{tabular}{|c|c|}
\hline Algorithm & TwoStep \\
\hline Inputs & 5 \\
\hline Clusters & 2 \\
\hline
\end{tabular}

Cluster Quality

\begin{tabular}{|c|c|c|c|c|}
\hline \multicolumn{3}{|c|}{ Poor } & Fair & Good \\
\hline-1.0 & -.05 & 0.0 & 0.5 & 1.0 \\
\hline
\end{tabular}

\begin{tabular}{|c|c|c|c|c|}
\hline \multicolumn{5}{|c|}{ Cluster Distribution } \\
\hline \multirow{3}{*}{ Cluster } & 1 & 68 & $85.0 \%$ & $85.0 \%$ \\
\cline { 2 - 5 } & 2 & 12 & $15.0 \%$ & $15.0 \%$ \\
\hline & Combined & 80 & $100.0 \%$ & $100.0 \%$ \\
\hline & 80 & & $100.0 \%$ \\
\hline
\end{tabular}

\section{Conclusions and Recommendations}

\subsection{Conclusions}

This study concludes that there is a significant effect of financial ratios, namely Debt Ratio, Asset Turnover and Gross Profit Margin on the financial performance, as measured by Return on Assets, of Philippine MSMEs. These entities should remain self-sufficient and self-reliant, without unreasonably depending on debts. In pursuing their respective businesses, they should adequately afford capital necessary to avoid needless borrowings. They should create contingency funds from which they can promptly supplement their capital when the need arises. When needed, these debts should be fittingly resorted to. They should guard against default risks from which huge interests and penalties arise, intensely depleting much resource.

Further, MSMEs should be optimally operated to generate sales by efficiently employing their resources. Concretely planned, they should wisely strategize how to best use their assets. They should extensively engage and earn the patronage of bigger and better customers through which they can increase their sales. Most importantly, they artistically advertise and stirringly sell only quality essentials.

Furthermore, MSMEs should wisely manage those controllable costs of sales. They should considerably curtail those discretionary costs and essentially eliminate those unnecessary costs in order to increase their gross profit margin. In controlling for costs, they should guard against compromising the quality of outputs.

Further, it is concluded that there is a factor structure that can adequately explain the variation among the financial factors affecting the financial performance of Philippine MSMEs. They should decisively design their planning, organizing, directing, implementing and controlling activities aimed to suitably nourish sustainability and efficiency indicated by sound financial ratios. Particularly, they should adequately provide and effectively utilize their assets in order to secure business continuity in the long run. Particularly further, they should efficiently employ their assets in order to reguarly achieve 
sound liquidity and profitability.

Furthermore, it concludes that there is a cohesive clustering that can separate the financial factors affecting the financial performance of Philippine MSMEs. They should work to sustain good ratios and improve poor ratios. They should analyze their strong and weak areas, creatively enhancing entrepreneurial potentials and productivity while eliminating business inefficiencies and ineffectiveness.

\subsection{Recommendations}

This paper recommends that stakeholders sustainably support MSMEs. The government should prudently provide and thoughtfully track financial and technological subsidies for MSMEs while educational institutions should dutifully deliver extension services to MSMEs whom they can partner with in creating entrepreneurial endeavors towards profitable communities. The public should profusely patronize the products and services of MSMEs who they help in MSME sustainability.

It is also recommended that in the context of the pandemic, future researches on financial factors affecting financial performances be conducted in order to create solutions that reinforce MSME resilience and responsiveness.

\section{REFERENCES}

[1] Jewalikar A.D., Shelke A., "Lean Integrated Management Systems in MSME Reasons, Advantages and Barriers on Implementation," Materials Today: Proceedings, vol. 4, no. 2, pp. 1037-1044, 2017. https://doi.org/10.1016/j.matpr.201 7.01.117

[2] Kumar R., Biswas A., "Innovative Financing and its Implications on MSME Sector in India," In Handbook of Research on Promotional Strategies and Consumer Influence in the Service Sector, IGI Global, pp. 421-433, 2016. DOI: 10.4018/978-1-5225-0143-5.ch025

[3] United Nations, "Micro-, Small and Medium-Sized Enterprises Day," United Nations, 2020. Online available from https://www.un.org/en/observances/micro-small-medi um-businesses-day

[4] The World Bank, "Small and Medium Enterprises (SMES) Finance," The World Bank, 2021. Online available from https://www.worldbank.org/en/topic/smefinance

[5] European Commission, "Unleashing the Full Potential of European SMEs," European Commission, 2020. Online available from https://ec.europa.eu/commission/presscorner/ detail/en/fs_20_426

[6] Association of Southeast Asian Nation, "MSME Day 2018," Association of Southeast Asian Nation, 2018. Online available fromhttps://asean.org/asean-economic-community /sectoral-bodies-under-the-purview-of-aem/micro-small-and -medium-enterprises/international-msme-day/
[7] Neicu A.I., Radu A.C., Zaman G., Stoica I., Rapan F., "Cloud Computing Usage in SMEs. An Empirical Study on SMEs Employees Perceptions," Sustainability, vol. 12, no. 4960, pp. 1-14, 2020. http://dx.doi.org/10.3390/su12124960

[8] Abalos W.F., "Social Networking Marketing of Micro, Small and Medium Enterprises in the Province of Tarlac," Review of Integrative Business and Economics Research, vol. 9, no. 2, pp. 128-157, 2020. http://buscompress.com/uploads/3/4/9 /8/34980536/riber_9-s2_33_s19-118_128-157.pdf

[9] Department of Trade and Industry, "2019 MSME Statistics," Department of Trade and Industry, 2019. Online available from https://www.dti.gov.ph/resources/msme-statistics/

[10] Ilas-Panganiban D., Mitra-Ventanilla R., "The New Philippine Innovation Laws: A Response to the Call of MSMEs and Start-Ups," GRUR International, vol. 69, no. 7, pp. 693-705, 2020. https://academic.oup.com/grurint/articleabstract/69/7/693/5864482

[11] Kaushik A., "MSME's Using Innovation and Competitiveness to Standing the Competitive World," Journal of Critical Reviews, vol. 7, no. 16, pp. 1246-1252, 2020.http://www.jcreview.com/fulltext/197-1593626094.pd $\mathrm{f}$

[12] Department of Trade and Industry, "MSMED Plan," Department of Trade and Industry, 2017. Online available from https://www.dti.gov.ph/negosyo/msme-resources/msm ed-plan/

[13] Association of Southeast Asian Nation, "ASEAN strategic plan for SME Development 2016-2025," Association of Southeast Asian Nation, 2015. https://asean.org/wp-content/ uploads/2015/12/SAP-SMED-Final.pdf

[14] Prameswari N.S., Suharto M., Afatara N., "Developing E-Commerce for Micro Small Medium Enterprise (MSME) to Cope with Cultural Transformation of Online Shopping," JDM (Jurnal Dinamika Manajemen), vol. 8, no. 2, pp. 188-198, 2017. https://journal.unnes.ac.id/nju/index.php/jd $\mathrm{m} /$ article/view/12759

[15] Biswas A., Singh K. "A Region-Wise Export Performance of MSME Sector in India and its Determinants," Journal of Critical Reviews, vol. 7, no. 11, pp. 521-530, 2020. DOI http://dx.doi.org/10.31838/jcr.07.11.94

[16] World Trade Organization, "Small Business and Trade," World Trade Organization, 2021 https://www.wto.org/english/tratop_e/msmesandtra_e/msme sandtra_e.htm\#top

[17] Devi E.S., Rajamohan D.S., "Differently Abled Entrepreneurs in India- Evolving Issues and Challenges," TEST Engineering and Management, vol. 82, pp. 9257-9261, 2020. https://www.researchgate.net/profile/Saranya-Elango/ publication/341481695_Differently_Abled_Entrepreneurs_i n_India-_Evolving issues_and_Challenges/links/5ec3bfcd 9 2851c11a8745a17/Differently-Abled-Entrepreneurs-in-India -Evolving-issues-and-Challenges.pdf

[18] Suhaili M., Sugiharsono S., "Role of MSME in Absorbing Labor and Contribution to GDP," Economics Development Analysis Journal, vol. 8, no. 3, pp. 301-315, 2019. https://doi.org/10.15294/edaj.v8i3.35229

[19] Singh S., Paliwal M., "Unleashing the Growth Potential of Indian MSME Sector," Comparative Economic Research, 
vol. 20 , no. 2 , pp. $35-52$, 2017. http://dx.doi.org/10.1515/cer $-2017-0011$

[20] Samantha G., "The Impact of Natural Disasters on Micro, Small and Medium Enterprises (MSMEs): A Case Study on 2016 Flood Event in Western Sri Lanka," Procedia Engineering, vol. 212, pp. 744-751, 2018. https://doi.org/10.1016/j.proeng.2018.01.096

[21] Prasetyo P. E., Setyadharma A., Kistanti N.R., "Social Capital: The Main Determinant of MSME Entrepreneurship Competitiveness," International Journal of Scientific \& Technology Research, vol. 9, no. 03, pp. 6627-6637, 2020. https://www.researchgate.net/profile/Eko-Prasetyo-29/publi cation/340760550_Social_Capital_The_main_determinant_ of_MSME_entrepreneurship_competitiveness/links/5e9c40 7da6fdcca78924db54/Social-Capital-The-main-determinantof-MSME-entrepreneurship-competitiveness.pdf

[22] Faisal S., MM S. (2018). "Crowdfunding as a Potential Avenue for Mitigating MSME Funding Issues,” International Journal of Research in Management, vol. 6, no. 1, pp. 1-4, 2018. https://www.researchgate.net/profile/Shaha -Faisal/publication/323935047_CROWDFUNDING_AS_A _POTENTIAL_AVENUE_FOR_MITIGATING_MSME_F UNDING_ISSUES/links/5ab379c1a6fdcc1bc0c289df/CRO WDFUNDING-AS-A-POTENTIAL-AVENUE-FOR-MITI GATING-MSME-FUNDING-ISSUES.pdf

[23] Husnunnida M., Alfiana F., "Improvement of MSME Performance through Behavior Analysis of Financial Statements Using Accounting Information Technology," Eurasia: Economics \& Business, vol. 10, no. 28, pp. 42-50, 2019. https://doi.org/10.18551/econeurasia.2019-10

[24] San Mateo A.I., Reyes-Ancheta R., "Business Finance," FASTBOOKS Educational Supply, Inc., 2018.

[25] Dar I.A., Mishra M., "Dimensional Impact of Social Capital on Financial Performance of SMEs," The Journal of Entrepreneurship, vol. 29, no. 1, pp. 38-52, 2020. https://doi.org/10.1177/0971355719893499

[26] Esubalew A.A., Raghurama A., "The Mediating Effect of Entrepreneurs' Competency on the Relationship Between Bank Finance and Performance of Micro, Small, And Medium Enterprises (MSMEs)," European Research on Management and Business Economics, vol. 26, no. 2, pp. 87-95, 2020. https://doi.org/10.1016/j.iedeen.2020.03.001

[27] Ombongi P.N., Long W., "Factors Affecting Financial Performance of Small and Medium Enterprises (SMEs): A Case of Manufacturing SMEs In Kenya," International Journal of Research in Business Studies and Management, vol. 5, no. 1, pp. 37-45, 2018.

https://www.ijrbsm.org/papers/v5-i1/4.pdf

[28] Prawirodipoero G.M., Rahadi R.A., Hidayat A., "The Influence of Financial Ratios Analysis on the Financial Performance of Micro Small Medium Enterprises in
Indonesia," Review of Integrative Business and Economics Research, vol. 8, no. 4, pp. 393-400, 2019. https://sibresearch.org/uploads/3/4/0/9/34097180/riber_8-s4 31_k19-126_393-400.pdf

[29] Cabrera M.E., Cabrera G.A., "Management Accounting," GIC Enterprises \& Co. Inc., 2017.

[30] Cruz-Manuel Z.V., " $21^{\text {st }}$ Accounting Process Basic Concepts and Principles,” Zenaida Vera Cruz Manuel, 2018.

[31] Daryanto W.M., "Financial Performance Analysis and Evaluation of Palm Oil Agroindustry: An Indonesia Experience," Jurnal Ilmiah Manajemen dan Bisnis, vol. 3, no. 1, pp. 108-126, 2017. https://repository.ipmi.ac.id/16/

[32] Cammayo E., Cammayo K.B., "Factors Affecting the Performance within the Micro, Small Medium Enterprise Sector in Isabela, Philippines," Journal of Critical Reviews, vol. 7, no. 11, pp. 3377-3386, 2020. http://www.jcreview.co m/fulltext/197-1595661264.pdf

[33] Suparlinah I., Purwati A.S., Putri N.K., Warsidi W., "Factors that Influence MSME Performance Improvement (Study on MSMEs of Women Entrepreneurs in Banyumas Regency)," Acta Universitatis Danubius, vol. 15, no. 7, pp. 108-121, 2019.https://www.ceeol.com/search/article-detail?id=87904 2

[34] Ratnawati K., "The Influence of Financial Inclusion on MSMEs' Performance through Financial Intermediation and Access to Capital," The Journal of Asian Finance, Economics, and Business, vol. 7, no. 11, pp. 205-218, 2020. https://www.koreascience.or.kr/article/JAKO202032462596 920.page

[35] Ni'matulHoiroh N.H., Izzah A., Rokhman M.T.N., Trisnawati N., Perdana S., "The Role of Financial Literacy, Use of Accounting Information System, Human Resources on SME Performance," International Journal of Innovative Science and Research Technology, vol. 5, no. 12, pp. 710-714, 2020. https://ijisrt.com/assets/upload/files/IJISRT20DEC390.pdf

[36] El-Ansary O., Al-Gazzar H., "Working Capital and Financial Performance in MENA Region," Journal of Humanities and Applied Social Sciences, vol. 3, no. 4, pp. 257-280, 2021. https://doi.org/10.1108/JHASS-02-2020-0036

[37] Sarstedt M., Ringle C., Hair J., "Partial Least Squares Structural Equation Modeling," In book: Handbook of Market Research, vol. 26, no. 1, pp. 1-40, 2017. https://doi.org/10.1007/978-3-319-05542-8_15-1

[38] Rita M.R., Utomo M.N. "An Entrepreneurial Finance Study: MSME Performance Based on Entrepreneurial and Financial Dimensions," Jurnal Keuangan dan Perbankan, vol. 23, no. 2, pp. 217-234, 2019. https://smartlib.umri.ac.id/assets/uploads /files/37e45-3076-9793-2-pb.pdf 